About authors:

Barycheva Lyudmila Yurievna, DMSc, Professor, Head of the Department of immunology; tel.: +79187405484; e-mail: for_ludmila@inbox.ru

Golubeva Marina Viktorovna, MD, DMSc, Professor, Head of the Department of childhood infectious diseases;

tel.: 79187468795; e-mail: mmvg@rambler.ru

Kuzmina Ekaterina Sergeevna, MD, Assistant of the Department of immunology; tel.: +79620104810; e-mail: katerinamedic@mail.ru

Rakitina Elena Nikolaevna, postgraduate student; tel.: +79624507653; e-mail: rakitina_1989@bk.ru

(c) Group of authors, 2019

UDC 616.735.5.002.61:34.49.003

DOI - https://doi.org/10.14300/mnnc.2019.14126

ISSN - 2073-8137

\title{
LEUKOCYTIC RESPONSES IN PERIPHERAL BLOOD AND PECULIARITIES OF BONE MARROW HEMATOPOIESIS IN ACUTE AND CHRONIC INFLAMMATION ON A BACKGROUND OF LOCAL REMOVAL OF NON-PHAGOCYTIC GRANULOCYTES
}

Sirak A. G. ' , Piskareva E. I. ', Magomedova O. G. ${ }^{1}$, Arutjunova A. P. ${ }^{1}$, Dolgashova M. A. ' , Didenko M. O. ', Andriutsa N. S. ${ }^{2}$, Kochkarova Z. M. ${ }^{1}$

${ }^{1}$ Stavropol State Medical University, Russian Federation

2 I. M. Sechenov First Moscow State Medical University (Sechenov University),

Russian Federation

\section{АЕЙКОЦИТАРНАЯ РЕАКЦИЯ ПЕРИФЕРИЧЕСКОЙ КРОВИ И ОСОБЕННОСТИ КОСТНОМОЗГОВОГО КРОВЕТВОРЕНИЯ ПРИ ОСТРОМ И ХРОНИЧЕСКОМ ВОСПААЕНИИ НА ФОНЕ АОКААЬНОГО УАААЕНИЯ НЕФАГОЦИТИРУЮЩИХ ГРАНУАОЦИТОВ}

\author{
А. Г. Сирак ${ }^{1}$, Е. И. Пискарева ${ }^{1}$, О. Г. Магоменова ${ }^{1}$, А. П. Арутюнова ${ }^{1}$, \\ М. А. Аолгашова ', М. О. Аиленко ', Н. С. Анариуца ${ }^{2}$, 3. М. Кочкарова ${ }^{1}$ \\ ${ }^{1}$ Ставропольский госуАарственный МеАицинский университет, Российская ФеАерация \\ 2 Первый Московский госуАарственный меАицинский университет \\ им. И. М. Сеченова (Сеченовский Университет), Российская ФеАерация
}

\footnotetext{
The aim of the present study was to investigate leukocytic responses in peripheral blood and the features of bone marrow hematopoiesis in acute and chronic inflammatory processes against a background of experimental localized removal of non-phagocytic granulocytes. Bone marrow hematopoiesis was assessed by calculating the total number of myelokaryocytes and the cellular composition of bone marrow obtained from the femurs of 24 male Wistar rats weighing 180-220 g. During the inflammatory process after prior localized removal of non-phagocytic granulocytes, hematopoiesis-especially lymphopoiesis-was enhanced, and there was a decrease in leukocyte counts from the bone marrow into the blood.
}

Keywords: acute inflammation, chronic inflammation, non-phagocytic granulocytes, experiment

Проведено изучение особенностей костномозгового кроветворения и лейкоцитарной реакции периферической крови при остром и хроническом воспалительном процессе на фоне локального удаления нефагоцитирующих гранулоцитов. Костномозговое кроветворение изучали путем подсчета общего количества миелокариоцитов и клеточного состава костного мозга, полученного из бедренной кости 24 крыс-самцов линии Wistar массой 180-220 г. Установлено, что при воспалительном процессе на фоне предварительного удаления НГ из очага происходит усиление гемопоэза, особенно лимфопоэза, и уменьшение поступления лейкоцитов из костного мозга в кровь.

Ключевые слова: острое воспаление, хроническое воспаление, нефагоцитирующие гранулоциты, эксперимент

For citation: Sirak A. G., Piskareva E. I., Magomedova O. G., Arutjunova A. P., Dolgashova M. A., Didenko M. O., Andriutsa N. S., Kochkarova Z. M. LEUKOCYTIC RESPONSES IN PERIPHERAL BLOOD AND PECULIARITIES OF BONE MARROW HEMATOPOIESIS IN ACUTE AND CHRONIC INFLAMMATION ON A BACKGROUND OF LOCAL REMOVAL OF NON-PHAGOCYTIC GRANULOCYTES. Medical News of North Caucasus. 2019;14(3):512-516.

DOI - https://doi.org/10.14300/mnnc.2019.14126 
Для цитирования: Сирак А. Г., Пискарева Е. И., Магомедова О. Г., Арутюнова А. П., Долгашова М. А., Диденко М. О., Андриуца Н. С., Кочкарова З. М. ЛЕЙКОЦИТАРНАЯ РЕАКЦИЯ ПЕРИФЕРИЧЕСКОЙ КРОВИ И ОСОБЕННОСТИ КОСТНОМОЗГОВОГО КРОВЕТВОРЕНИЯ ПРИ ОСТРОМ И ХРОНИЧЕСКОМ ВОСПАЛЕНИИ НА ФОНЕ ЛОКАЛЬНОГО УДАЛЕНИЯ НЕФАГОЦИТИРУЮЩИХ ГРАНУЛОЦИТОВ. Медицинский вестник Северного Кавказа. $2019 ; 14(3): 512-516$. DOI - https://doi.org/10.14300/mnnc.2019.14126

A II mechanisms and manifestations of inflammation are interconnected, forming single functional system. The system is successful because it is controlled by many factors, including localized tissue homeostatic mechanisms (mediator systems) and integrative systems of the body (nervous, endocrine, and immune systems) [1, 2]. The inflammatory process involves a branched multicomponent complex of mechanisms that periodically become dysfunctional. In such instances inflammation becomes a dysregulatory pathology rather than a protective adaptive reaction [3].

At the effector level hematological changes play a leading role in the formation of nonspecific and specific reactions in the body, and in combination with manifestations of components of connective tissue and the microvasculature they make up the essence of the inflammatory process and determine the reactivity and resistance of a macroorganism as a whole $[4,5]$. The blood system contributes to the emergence and maintenance of the focus of leukocyte infiltration, which is the main component of inflammation. In inflammation sequential interconnected changes in bone marrow and peripheral blood influence the formation of the leukocyte focus $[6,7,8]$. White blood cells are the main effector factors in inflammation. After entering connective tissue from the bloodstream they contribute to both specific and nonspecific protection by way of killer activity, exocytosis of biologically active substances, and phagocytosis, as well as antibody synthesis. Phagocytic cells constitute the main protective mechanism against bacterial infection $[9,10,11]$.

The least studied aspects of errant or dysregulated inflammation are the mechanisms of leukocyte infiltration involved, the associated changes in cell phases, and the transition from pathological inflammation to its subsidence. The aims of the present study were to investigate peripheral blood leukocyte responses and the features of bone marrow reactions involved in the inflammatory process, against a background of experimental localized removal of non-phagocytic granulocytes.

Material and Methods. Twenty four male Wistar rats weighing 180-220 g were used in the current study, and they were assigned to either a control group or an inflammation group ( $n=12$ per group). Chronic inflammation was induced in the experimental via a well-known model of formalin edema and experimental subcutaneous granuloma [12]. The standard procedure was used to induce aseptic inflammation. Under light ether anesthesia $0.1 \mathrm{~mL}$ of $2 \%$ formalin was injected into the hind paws of rats under the plantar aponeurosis. Leg volumes were measured with an oncometer (GONOTEC, Germany) [13]. The masses of the granulomas subsequently formed were determined using a torsion balance (VesMaster, Russia). Dynamic changes in the inflammatory process were assessed starting from 6 hours after experimental induction of inflammation, and thereafter on days $1,3,7,14$, and 28 . The rats in the control group were administered sterile saline.

Bone marrow hematopoiesis was investigated by counting the total number of myelokaryocytes and assessing the cellular composition of bone marrow (MiniMed, Russia) [13]. To obtain bone marrow each rat femur was isolated, soft tissues were removed from it, and the channel was thoroughly washed with $1 \mathrm{~mL}$ of $3 \%$ acetic acid. The acetic acid used in this process contained gentian violet stain, to facilitate subsequent assessments. The bone marrow was then suspended, collected into a melanger for white blood cells, and diluted in $3 \%$ acetic acid. The total number of myelokaryocytes per femur was calculated using a Goryaev camera (BioVitrum, Russia) [13].

The cellular compositions of femur bone marrow samples were investigated by counting myelograms in smears, followed by calculations to determine absolute numbers of cells based on the total karyocyte count (TKC). To prepare the aforementioned smears, bone marrow was squeezed from the distal end of the femur onto defatted glass and diluted with isological serum (Agat-Med, Russia). Smears were fixed in methanol and stained with azure II-eosin in accordance with the Romanovsky - Giemsa method [13].

Peripheral blood leukocyte reactions were investigated by counting the total number of leukocytes (TNL) in blood, as well as the leukocyte formula with the determination of the functional state of leukocytes. TNL was calculated using a Goryaev camera. Prior to applying the leukocyte formula, blood smears were fixed in methanol and stained with azure II-eosin. After utilizing the leukocyte formula the absolute number of cells was calculated based on the total number of leukocytes [13].

Statistical assessments were conducted via one-way analysis of variance and the Newman-Keysl multiple-test criterion using Primer of Biostatistics 4.03 for Windows software, and $p<0.05$ was deemed to indicate statistical significance. All experimental studies were conducted in accordance with the requirements of good laboratory practice (set forth in the national standard «Principles of Good Laboratory Practice» GOST R 53434-2009), in compliance with the International Principles of the European Convention on the Protection of Vertebrate Animals Used for Experiments and Other Scientific Purposes (Strasbourg, 1986), in accordance with international recommendations for biomedical research using animals (1985), General Ethical Principles of Experiments on Animals, the Rules of Laboratory Practice in the Russian Federation (Order of the Ministry of Health of the Russian Federation № 267 of 06/19/2003), and the positive conclusion of the ethics committee in vivarium conditions on the basis of the Stavropol State Agrarian University (Russian Federation).

Results and Discussion. During the course of inflammation in models of formalin edema and experimental subcutaneous granuloma, compared to control animals the TKC in bone marrow decreased somewhat by the $6^{\text {th }}$ hour and more substantially by the $24^{\text {th }}$ hour (Fig. 1). This was likely due to leaching of mature cells from the bone marrow postmitotic reserve pool into the blood, from where they then entered the focus of inflammation. By the $3^{\text {rd }}$ day TKC was restored, and it slightly exceeded the initial TKC, which was presumably a phenomenon associated with the activation of hematopoiesis. By the $7^{\text {th }}$ day TKC decreased again, both in comparison with the $3^{\text {rd }}$ day in experimental rats and in comparison with control rats, reflecting further release of 
karyocytes into the blood and the focus of inflammation. From the $14^{\text {th }}$ day to the $28^{\text {th }}$ day there was an escalating increase in TKC, both in comparison with the $7^{\text {th }}$ day in activation of hematopoiesis. This was accompanied by the development of bone marrow hyperplasia, and TKC on the $28^{\text {th }}$ day was approximately 4 times that of control rats. experimental rats and with control rats, indicating further

number of monocytes only doubled. This was presumably due to more intensive release of the latter.

Sharp increases in TKC and the levels of all other cell types investigated were observed in the control group when the inflammatory process occurred and before the removal of non-phagocytic granulocytes (NGs). In our opinion this was likely associated with a decrease in the release of cells from bone marrow into the blood and into tissue, and as a result, increased hematopoiesis. NGs may reduce the entry of cells from bone marrow into the blood and tissue, and inhibit hematopoiesis (Fig. 2). This is concordant with the observation that during inflammation against a background of NG removal, from the $6^{\text {th }}$ hour to the $7^{\text {th }}-14^{\text {th }}$ day of TKC the levels of individual cell types exceeded normal levels. During the inflammatory process against a background of NG removal, the numbers of neutrophils and macrophages at the focal site of inflammation decreased and the number of lymphocytes increased; i.e., increases in the numbers of neutrophils and monocytes in bone marrow may be largely due to decreases in their release into the blood, while an increase in lymphocytes may be associated with increased lymphopoiesis.

Notably the first peak in the increase in cells in bone marrow occurred on the $7^{\text {th }}-14^{\text {th }}$ day, which presumably reflects more intense hematopoiesis. On the $21^{\text {st }}$ day the number of myelokaryocytes in bone marrow slightly

Fig. 1. Bone marrow hematopoiesis during the natural course of chronic inflammation $\left(x 10^{9} / \mathrm{L}\right),(\mathrm{M} \pm \mathrm{m}, \mathrm{n}=6)$. The data differ statistically significantly from those of the control group $(p<0.05)$

Similar observations were made with regard to all types of karyocytes. Notably however, instead of the amounts of mature and immature neutrophils decreasing by the $6^{\text {th }}$ hour a pronounced increase was observed, and by the $24^{\text {th }}$ hour the number of mature neutrophils peaked. This may have been because the controls were not intact rats, but rats taken 24 hours after the creation of experimental models, i.e., rats that already had, as indicated above, moderate acute inflammation due to mechanical tissue damage caused by the introduction of formalin and, accordingly, the hematopoiesis process had started. In other words, the $6^{\text {th }}$ and $24^{\text {th }}$ hours of the experiment actually correspond to the $30^{\text {th }}$ and $48^{\text {th }}$ hours from the onset of inflammation, i.e., the time determining the activation of hematopoiesis. It is known that granulocytopoiesis commences very soon after the initiation of inflammation.

In rats with experimentally induced inflammation there was a significant decrease in the number of monocytes in bone marrow by the $6^{\text {th }}$ or the $24^{\text {th }}$ hour, and a significant decrease in the number of lymphocytes by the $24^{\text {th }}$ hour. This may have been due to their abundant release into the blood, destined for the focal site of inflammation, as these cells are effectors of chronic inflammation.

In bone marrow a progressive recovery or increase in all types of cells compared with initial levels began from the $14^{\text {th }}$ day of the inflammatory process and peaked on the $28^{\text {th }}$ day, indicating pronounced activation of hematopoiesis. This typically resulted in bone marrow hyperplasia. A likely cause is the need for increased entry of leukocytes, especially monocytes, into the pathological focus due to the persistence of inflammation. Concordantly, while TKC and the levels of other cell types increased by $3-5$ times in rats with experimentally induced inflammation, the decreased again, i.e., repeated release of cells into the blood was not observed on the $7^{\text {th }}$ day but on the $21^{\text {st }}$, which may indicate reduced migration of cells into the blood. By the $28^{\text {th }}$ day the number of karyocytes was noticeably restored and barely differed from original levels, with the exception of a significantly smaller number of monocytes. This was apparently due to their predominant release into the bloodstream and consequent accumulation at the focal site of inflammation during this period of time. Moreover, in comparison with the natural course of inflammation only the number of mature neutrophils significantly increased, which corresponds to the general pattern of a decrease in neutrophil migration to the focal site of inflammation against a background of preliminary removal of NG from that site.

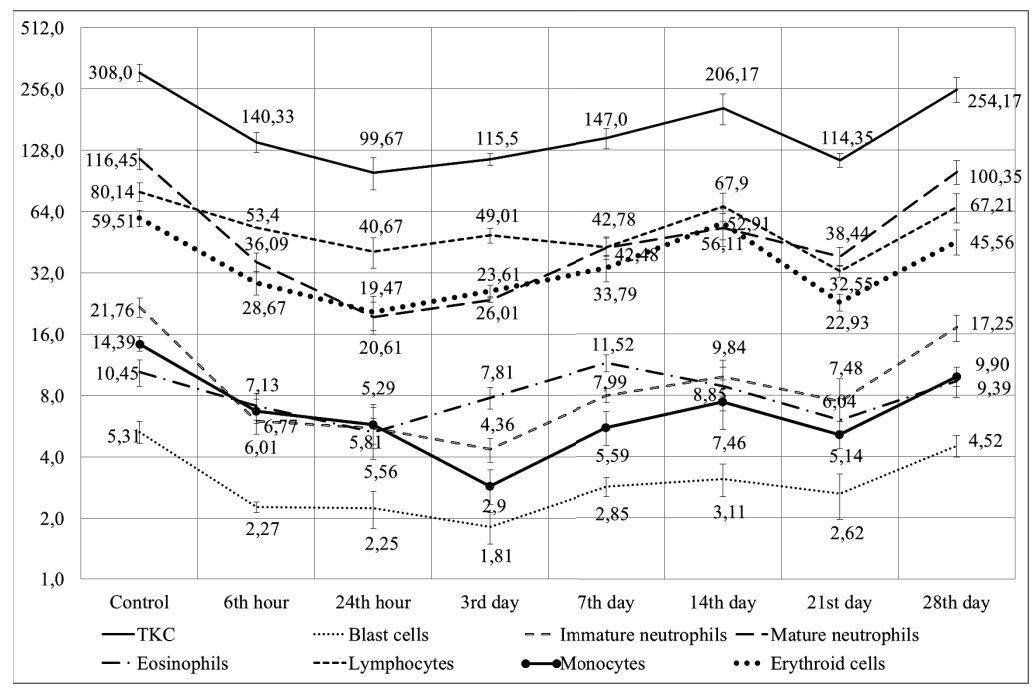

Fig. 2. Bone marrow hematopoiesis during chronic inflammation against a background of local non-phagocytic granulocyte removal $\left(x 10^{9} / \mathrm{L}\right)$, $(\mathrm{M} \pm \mathrm{m}, \mathrm{n}=6)$. The data differ statistically significantly from those of the control group $(p<0.05)$ 
With regard to leukocyte responses in peripheral blood, during inflammation transient leukopenia was not observed (Fig. 3), which was apparently because in the formalin edema and subcutaneous granuloma rats inflammation activated hematopoietic processes. Thus, leukocytosis was observed from the $24^{\text {th }}$ hour and lasted for 28 days. The maximum increase was observed on the $7^{\text {th }}$ day, which corresponded with the repeated release of cells from bone marrow into the blood.

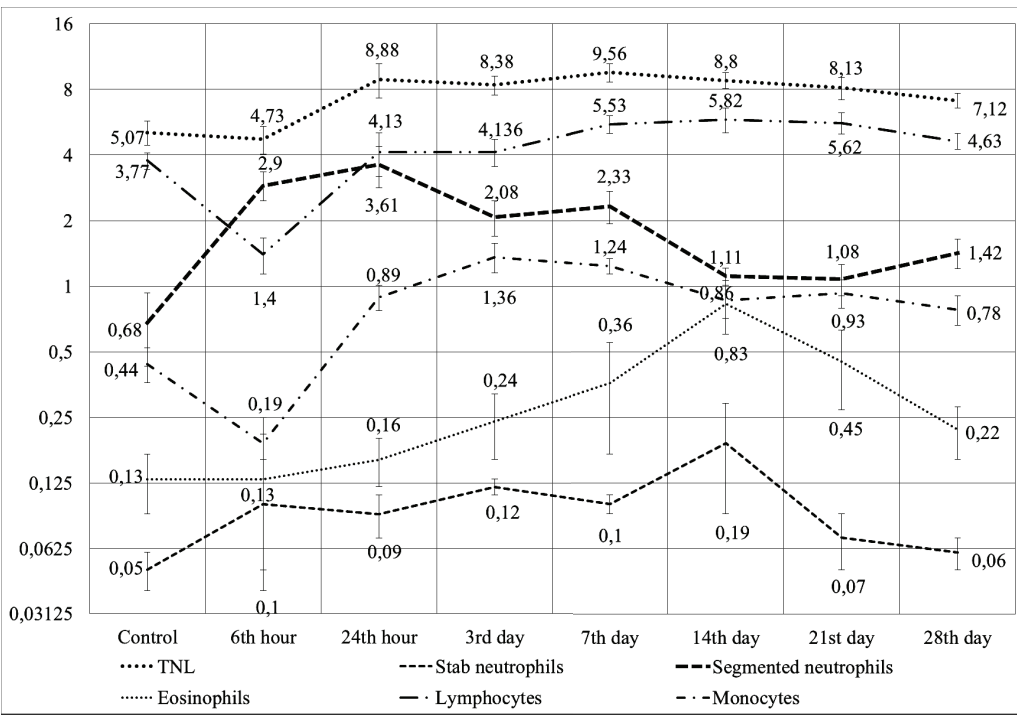

Fig. 3. Leukocyte responses in peripheral blood during the natural course of chronic inflammation $\left(\times 10^{9} / \mathrm{L}\right),(\mathrm{M} \pm \mathrm{m}, \mathrm{n}=6)$. The data differ statistically significantly from those of the control group $(p<0.05)$

On the $3^{\text {rd }}-7^{\text {th }}$ day a significant increase in the number of stab neutrophils was detected, with maximum values observed on the $3^{\text {rd }}$ day, which coincided with the first peak of hematopoiesis activation. The number of segmented neutrophils was significantly increased at the $6^{\text {th }}$ hour, and on the $28^{\text {th }}$ day. On the first day the increase was associated with the release of mature neutrophils from the bone marrow postmitotic reserve pool (redistributive leukocytosis). On the $3^{\text {rd }}$ day it was associated with the activation of hematopoiesis, and on the $28^{\text {th }}$ day it was associated with the repeated activation of hematopoiesis due to the persistence of inflammation.

Eosinophilic leukocytosis was observed on the $14^{\text {th }}$ day and was presumably a reflection of the involvement of a degree of autoimmunity that manifested as a component of the chronic inflammation. Notably lymphopenia at the $6_{\text {th }}$ hour and lymphocytosis at the $7^{\text {th }}-21^{\text {st }}$ days, as well as monocytopenia at the $6^{\text {th }}$ hour and monocytosis at the $1^{\text {st }}-28^{\text {th }}$ days, reflect increased migration of monocytes and lymphocytes to the focal site of inflammation. Initially this occurs as a result of circulating leukocytes, then it continues as a result of the entry of cells from bone marrow into the blood, and to the pathological focal site of chronic inflammation.

When NG was removed in the control rats TNL and the levels of all types of leukocytes sharply increased, and there was a corresponding increase in the number of TKC in bone marrow. The number of mature neutrophils in the bone marrow increased by 8.4 times, segmented neutrophils in the blood increased by 12.2 times, eosinophils increased by 3.0 times in bone marrow and 7.6 times in blood, and monocytes increased by 3.5 times in bone marrow and 3.8 times in blood. In our opinion these increases are associated with a decrease in the output of these cells from the blood into the tissues when NG is removed. Concurrently the number of lymphocytes increased by 5.6 in bone marrow and 3.2 times in blood, indicating enhanced output of lymphocytes from the blood into the tissue under these conditions. Concordant changes in the total number of cells were observed. TKC in bone marrow increased by 5 times, and TNL in the blood increased by 4.6 times. This reflects a general decrease in the release of karyocytes from the bone marrow into the blood. With regard to the dynamics of inflammation, total number of leukocytes was significantly less than it was during the natural course of the process. On the $1^{\text {st }}$ day the number of SNs - on the $3^{\text {rd }}$ day; NS - on the $6^{\text {th }}-24^{\text {th }}$ hours, lymphocytes - on the $1^{\text {st }}$ and $21^{\text {st }}$ days; monocytes - on the $3^{\text {rd }}-7^{\text {th }}$ day.

It is known that the number of leukocytes in the blood reflects their migration from the blood to the focus of inflammation and their entry from the bone marrow into the blood [3,9]. Given the changes in the numbers of leukocytes at the pathological focal site, it can be assumed that a smaller number of neutrophils and monocytes in the blood is associated with a decrease in their entry from the bone marrow into the blood. With regard to lymphocytes, it is likely to correspond with their increased migration from the blood to the pathological focal site.

Conclusions. Against a background of prior removal of NG from the focal site of inflammation, there is an increase in hematopoiesis (especially lymphopoiesis) and a decrease in the entry of leukocytes from the bone marrow into the blood. Concurrently, more lymphocytes migrate to the focus of inflammation, and less neutrophils and monocytes migrate there. Therefore, the results of the present experimental study indicate that in acute and chronic inflammation in vivo non-phagocytic granulocytes limit hematopoiesis (especially lymphopoiesis) and enhance the release of karyocytes from bone marrow into the blood.

Disclosures:

The authors declare no conflict of interest.

Acknowledgment:

We thank Dr Owen Proudfoot from Edanz Group (www.edanzediting.com/ac) for editing a draft of this manuscript.

\section{References}

1. Ortega-Gómez A., Perretti M., Soehnlein O. Resolution of inflammation: An integrated view. EMBO Molecular Medicine. 2013;5(5):661-674.

https://doi.org/10.1002/emmm.201202382

2. Headland S. E., Norling L. V. The resolution of inflammation: Principles and challenges. Seminars in Immunology. 2017;27(3):149-160.

https://doi.org/10.1016/j.smim.2015.03.014
3. Moskalev A. V., Rudoy A. S., Apchel A. V., Shangin A. B. Role of neutrophilic granulocytes in the immunoinflammatory process. Vestnik Rossijskoj voenno-medicinskoj akademii. - Bulletin of the Russian Military Medical Academy. 2016;(4):191-195.

4. Alexeeva N. T. The Participation of Cell Component in Regeneration of Wounds. Zhurnal anatomii i gistopatologii. Journal of Anatomy and Histopathology. 2014;3(1): 9-15. 
5. Wynn T. A., Vannella K. M. Macrophages in Tissue Repair, Regeneration, and Fibrosis. Immunity. 2016;44(3):450462. https://doi.org/10.1016/j.immuni.2016.02.015

6. O'Sullivan J. A., Carroll D. J., Moreno-Vinasco L., Cao Y. Bochner B. S. [et al.] Frontline science: characterization of a novel mouse strain expressing human siglec-8 only on eosinophils. Journal of Leukocyte Biology. 2018;104(1):1119. https://doi.org/10.1002/JLB.2HI0917-391R

7. Platzer B., Singer K., Panduro M., Lexmond W. S., Fiebiger $E$. [et al.] Dendritic cell-bound ige functions to restrain allergic inflammation at mucosal sites. Mucosal Immunolo gy 2015:8(3):516-532. https://doi.org/10.1038/mi.2014.85

8. Sugimoto M. A., Ribeiro A. L. C., Costa B. R. C., Vago J. P., Lima K. M. [et al.] Phagocytes, granulocytes, \& myelopoiesis: Plasmin \& plasminogen induce macrophage reprogramming \& regulate key steps of inflammation resolution via annexin A1. Blood. 2017;129(21): 2896-2907. https://doi.org/10.1182/blood-2016-09-742825
9. Mosser D. M., Edwards J. P. Exploring the full spectrum of macrophage activation. Nature Reviews Immunology. 2008:8(12):958-969. https://doi.org/10.1038/nri2448

10. Breedveld A., van Egmond M., Kormelink T. G., de Jong E. C. Granulocytes as modulators of dendritic cell function. Journal of Leukocyte Biology. 2017;102(4):10031016. https://doi.org/10.1189/jlb.4MR0217-048RR

11. Uciechowski P., Rink L. Basophil, eosinophil, and neutrophil functions in the elderly. Immunology of Aging. 2014;10(1):47-63. https://doi.org/10.1007/978-3-642-39495-9 5

12. Cong Hong Hanh Khaziakhmetova $\mathrm{V}^{-} \mathrm{N}$ Ziganshina L. E. Modeling Inflammatory Edema: Are the Models Interchangeable? Experimental'naya i klinicheskaya pharmakologiya. - Experimetntal and Clinical Pharmacology. 2015;78(7):24-31.

13. Zimatkin S.M. Histology. Minsk, 2014

About authors:

Sirak Alla Grigorievna, MD, PhD, Professor, Head of Departament of histology; tel.: +78652356219; e-mail: kafedragist@yandex.ru

Piskareva Elena Ivanovna, MD, Associate Professor; tel.: +79887086717; e-mail: ivga.stgma@mail.ru

Magomedova Oksana Gasamutdinovna, Assistant; tel.: +79286319997; e-mail: oksana.magomedova@bk.ru

Arutjunova Alina Pavlovna, Assistant; tel.: +79881177100; e-mail: alina77100@gmail.com

Dolgashova Marina Aleksandrovna; MD, Associate Professor; tel.: +79054135520; e-mail: dolgashova@mail.ru

Didenko Maria Olegovna, postgraduate student; tel.: +79283406900; e-mail: dr.maria.didenko@gmail.com

Andriutsa Natalia Sergeevna, MD, Associate Professor of Departament of pathophysiology; tel.: +79161164747; e-mail: natiandriutsa@mail.ru

Kochkarova Zuchra Magomedovna, postgraduate student; tel.: +78652352628; e-mail: azrch_1991@rambler.ru

(C) Group of authors, 2019

UDC 616.71-089.844

DOI - https://doi.org/10.14300/mnnc.2019.14127

ISSN - 2073-8137

\section{EXPERIMENTAL MODELING OF AURICULAR CARTILAGE ON ARTIFICIAL IMPLANTABLE MATRIX}

Gaboyan A. N. ' , Sukorceva N. S. ${ }^{1}$, Aganesov G. A. ${ }^{1}$, Sinelnikov M. Y. ${ }^{3}$, Reshetov I. V. ${ }^{1}$, Nikolenko V. N. ${ }^{1}$, Kochurova E. V. ${ }^{1}$, Vorobyov A. A. ${ }^{2}$

${ }^{1}$ I. M. Sechenov First Moscow State Medical University (Sechenov University),

Russian Federation

2 Volgograd State Medical University, Russian Federation

${ }^{3}$ Institute for Regenerative Medicine, Sechenov University, Moscow, Russian Federation

\section{ЭКСПЕРИМЕНТААЬНОЕ МОАЕАИРОВАНИЕ РЕКОНСТРУКЦИИ УШНОГО ХРЯЩА НА ПОАИОЖКЕ}
А. Н. Габоян ${ }^{1}$,
Н. С. Сукорцева '
Г. А. Аганесов ${ }^{1}$
М. Е. Синельников ${ }^{3}$,

И. В. Решетов ${ }^{1}$,

1 Первый Московский госуАарственный меАицинский университет

им. И. М. Сеченова (Сеченовский Университет),

Москва, Российская Фелерация

2 ВолгограАсКий госУАарственнЫЙ МеАицинсКиЙ Университет, Российская ФеАерация

${ }^{3}$ Институт регенеративной меАицины Первого Московского ГосуАарственного МеАицинского Университета им. И. М. Сеченова (Сеченовский Университет), Российская ФеАерация

Reconstruction of cartilage tissue is an essential aspect of modern reconstructive surgery. This experimental study outlines the development and in vivo application of autologous cartilage tissue with flexible configuration with a Reperen on-lay mesh. As a result of the experiment, a novel method was developed for fixation of cartilage transplants in the recipient zone in a predetermined configuration. This allows for shape retention in the recipient zone during cartilage transplantation.

Keywords: cartilage autotransplantation, reperen, cartilage modeling, cartilage reconstruction, tissue reparation 